\title{
Street Queens: New Orleans Brass Bands and the Problem of Intersectionality
}

\author{
Kyle DeCoste / Columbia University
}

\begin{abstract}
The members of the all-female Original Pinettes Brass Band contest the male domination of the New Orleans brass band scene. Playing music on male-gendered instruments, they queer the normative relationship between instruments and musicians and carve out a space for female musicianship. This essay deconstructs their songs and performance decisions as agential and subjective sites of black feminist thought put into action to subvert the brass band patriarchy. The Pinettes force us to view the New Orleans brass band scene as an intersectional site where gender is a central element in the construction and consolidation of power relationships.
\end{abstract}

I sit sit at a table in the dim lighting of a neighborhood bar in New Orleans. The low ceiling amplifies and compresses the laughter and chitchat of the bar's fifty patrons, who have somehow continued their conversations the entire time they've been here despite the volume of a ten-piece brass band, which makes verbal communication barely possible. ${ }^{1}$ As the band reaches consensus on the next song, one musician turns to the microphone and, as so many other performers do throughout the city, invites the women in the audience to take to the dance floor: "Alright, y'all. So we gonna do this one, and if you want to try to sing it with us, sing it if you know it. Ladies, get crunk! Get on the dance flooooooor!" The snare drummer counts the band in with a familiar "1 234 ," and the other musicians raise trombones, a sax, a tuba, and trumpets to their mouths, delivering a brassy groove over thuds of a bass drum to inspire dancing and audience participation.

This seemingly quotidian show differs from others in that the music is furnished by the Original Pinettes Brass Band, composed entirely of women. Female brass band musicians are in the minority in New Orleans, comprising ten or so musicians in a city with approximately fifty bands and making the Pinettes a

(C) 2017 by the Society for Ethnomusicology 
departure from implicit understandings of who can constitute a brass band. In a patriarchal community of musicians where instruments are male gendered, the Pinettes loudly disrupt social norms with the blasts of brass and percussion instruments.

The available scholarship on brass bands has thus far focused almost exclusively on racial identity and how the ensemble of portable instruments originally associated with the military became racially encoded as black. Partially due to the relative absence of women in brass bands, gender identity has been neglected as a category of analysis, reproducing the bias of the scene at large. There are major studies that make no mention of gender whatsoever (Schafer 1977; Knowles 1996; White 2001). Of the twenty-nine interviewees in Mick Burns's (2006) edited collection of contemporary brass band oral histories, the only woman featured was bar owner Donna Patiagowski-Sims, and women musicians weren't even mentioned. Matt Sakakeeny's 2013 ethnography, Roll with It: Brass Bands in the Streets of New Orleans, brought class analysis into New Orleans music discourse, which heavily prioritized race over other categories of analysis. Instead of simply celebrating the city's music, Sakakeeny emphasizes the concerns of its creators, who are often subject to urban violence, poverty, and racial and economic marginalization, arguing that musicians use brass band instruments to articulate power. Despite this move toward intersectionality, the silence of women in Roll with It was known to Sakakeeny when the book went to press, as he readily acknowledged that his "focus on black men perpetuates the marginalization of black women in scholarly studies" (2013:202).

With the ethnomusicological turn in New Orleans music scholarship toward concerns of social justice and intersectionality, a foundation existed for me to consider gender as an element within a broad field of societal power relations in the New Orleans brass band community. Framing the Pinettes in a broader context of nonnormativity necessitates that I analyze more than just a single vector of oppression (gender) and instead use a more robust theoretical framework that considers other identity categories. I aim to bring the Pinettes' performances and discourse into productive conversation with black feminist theories.

The decisions the Pinettes make about their music on and off the stage are political and are a source of black feminist knowledge. Activist anthropologist Irma McClaurin identified lived experience as a crucial component of black feminist theory, defining a black feminist perspective as "an embodied, positioned, ideological standpoint" that is centered on experience as a way of knowing (2001:63). The songs the Pinettes play come from lived experience, invoked by Patricia Hill Collins (2000) and other scholars as a criterion for credibility among black women when making knowledge claims. Black feminist thought is more than this, though. It is the confluence of the commonplace taken-for-granted 
knowledge of black women and the more specialized expert knowledge of black women who emerge from a group as representative (Collins 2000).

One of black feminist theory's foundational and broadly applicable tenets is that it questions the position of the theorist (Kelley 2002). ${ }^{2}$ It can - and indeed often does-come from alternative means of knowledge production, such as music making. The blues, in particular, have been a rich site where scholars have excavated black feminist knowledge (Carby 1986; Harrison 1990; Davis 1999). I hope to expand this scholarship by taking into account the authorship and circulation of songs, considering them not as decontextualized textual sources of black feminist thought but rather as vital and permeable sonic entities (Lordi 2013). Extending this approach to recorded songs into the anthropological domain, one might ask how songs communicate black feminist thought in performance. Using literary analysis, Emily Lordi argues that singers "create culture through their subtle yet inimitable musical choices, which expand our understanding of what can be expressed, and how" (9, emphasis mine). This line of thinking frames performative choices as subjective and agential acts of authorship that expand beyond strict Western notions of composition to include variations in performance. In the brass band scene, bands seek to please crowds; they change lyrics and song selections based on their interpretation of their audience's expectations. Collins argues that "viewing Black women's ideas that emerge from one social context as a canon to be celebrated or criticized runs the risk of reducing Black feminist thought to an academic commodity. A better approach treats Black feminist thought as a dynamic system of ideas reactive to actual social conditions" (1998:9). To view brass band songs as having only one definitive set of lyrics or arrangement would be to deny the vitality of the musical form and the agency of musicians who adapt and change songs according to their social and economic conditions. Angela Davis argues that "not all progressive art needs to be concerned with explicitly political problems.... [A] love song can be progressive if it incorporates a sensitivity toward the lives of workingclass women" (1990:200). A consideration of how the Pinettes add songs to a preexisting "canon" of brass band repertoire and revoice familiar songs from a collective perspective elicits new questions of what constitutes the political.

The Pinettes' song choices and the different versions they play when in different performance situations have led me to ask: How might songs communicate black feminist knowledge when they change across performance contexts? In other words, how does black feminist theory look in praxis? By looking at the Pinettes' performance decisions on and off the stage, I show how the Pinettes deal with black feminist concerns and perform their identities. I argue that the Pinettes use their songs to articulate black feminist thought through the active construction of situational collective identities. As such, their songs are not only 
sites of knowledge but also tools of subversion; they operate as black feminist theory in practice.

This essay should be read with an understanding of who is writing it. I write from the vantage point of a white male who relocated to New Orleans from Canada in 2013 (i.e., an outsider in every way to the Pinettes' social identities). This presents limits in my understanding because my lived experience is in no small part defined by the givenness of my social location. These ontological "constraints," however, don't mean that my perspective or the perspectives of anyone in this essay are fixed within social categories. Alice Walker asserted that "the truth about any subject only comes when all sides of the story are put together, and all their different meanings make one new one. Each writer writes the missing parts to the other writer's story" (1983:49). Because I am a white, straight, cisgender, working-class, Canadian male, my ability to write reflexively from an outsider identity can have intrinsic value in that it can bring perspectives together and, in doing so, inch closer to the truth. By writing reflexively, I also, hopefully, create a space for anthropologists whose words could be discredited solely on the basis of their marginalized identities (Newton 1996).

At times, my subject position has been difficult because I can't use my experience as a white male in a system that privileges my identity to speak directly to the lived experiences of black women. Paraphrasing the viewpoint of civil rights activist Pauli Murray (1970), Patricia Hill Collins suggests that "without a commitment to human solidarity . . . any political movement-whether [black] nationalist, feminist, or anti-elitist-may be doomed to ultimate failure" (2017:398).

The particularities of my subject position should be neither glorified nor minimized. I speak from a standpoint that reflects the partiality of my lived experience, and this is something that resonates at the nexus of anthropology and black feminism. Collins herself champions partiality, noting that it is this partiality and not universality that is "the condition of being heard" (2000:270). This essay serves as a heterophonic blending of partial voices-my voice implicitly as the author and the Pinettes' voices explicitly_-for the purpose of moving closer to a multi- and intersubjective understanding of gender in the New Orleans brass band community. ${ }^{3}$ By focusing this study on the Pinettes, I attempt to centralize identities and avenues of investigation that have been marginalized in the scholarship. The example of the Pinettes forces us to reconsider the domain of brass band music as one not only where brass band instruments articulate power but also where gender is a primary element in the construction and consolidation of this power (Sakakeeny 2013).

The Pinettes got their start in 1991 at St. Mary's Academy, a private Catholic girls' school. Taking direction from bandleader Jeffery C. Herbert, they began playing New Orleans-style jazz in what Herbert at the time called a "Dixieland 
band" (Christie Jourdain, interview with the author, March 17, 2014, New Orleans, Louisiana). After experimenting with contemporary hip-hop- and funk-influenced brass band music and receiving a favorable response from audiences, Herbert decided to refashion the musicians to play in the contemporary style. His idea was to capitalize on the possible commercial success of an allfemale brass band in order to help the band members' parents pay for tuition. Herbert dubbed the band the Pinettes (a feminization of the name of his own band, the Original Pinstripe Brass Band), and it began performing outside of school settings.

Like many brass bands in the city, the Pinettes have experienced much turnover in membership over the years. In the current lineup, only Christie Jourdain and Dee Holmes are original members, and their tenures have been punctuated by their pursuit of college educations elsewhere. When Hurricane Katrina struck New Orleans on August 29, 2005, band members temporarily resettled in other cities throughout the United States. Upon Christie Jourdain's return to the city, she took leadership of the band and recruited new band members because some members, greatly affected by the traumatic emotional and economic effects of the storm, decided not to come back to New Orleans. Since regrouping after the storm, the Pinettes have released an album entitled Finally and have gained attention from local and national musicians and media for their music and gendered remaking of the New Orleans brass band tradition.

\section{Bullet's Sports Bar}

I dismount my bicycle, lock it to a stop sign, and head toward the scent of barbecued smoked sausages and fried fish that engulfs Bullet's Sports Bar in the heart of New Orleans's Seventh Ward. It's a neighborhood bar in the middle of a residential neighborhood, and I'm one of only a few patrons to visit from another locality, having biked forty minutes to get there. The bar door, which faces the corner of North Dorgenois Street and A. P. Tureaud Avenue, is flanked by two windows, each with beer signs that illuminate the sidewalk below. At first glance, this is the only noticeable signage, but upon further inspection, a white sign placed high on the wall to the left of the door presumably says "Bullet's." The lettering is faded, but the bar's reputation is substantial enough in the neighborhood that the sign isn't functional, and it no longer needs to be (figure 1). The building has been the location of a neighborhood bar since the 1950s, and many patrons now in their sixties have been visiting the watering hole since the days of their youth.

Crowded outside the door, the Pinettes talk among themselves before going inside to play their weekly Friday night gig. They greet me with a collective "Kyle!" I hug a couple of them and make a bit of small talk, ending with an 


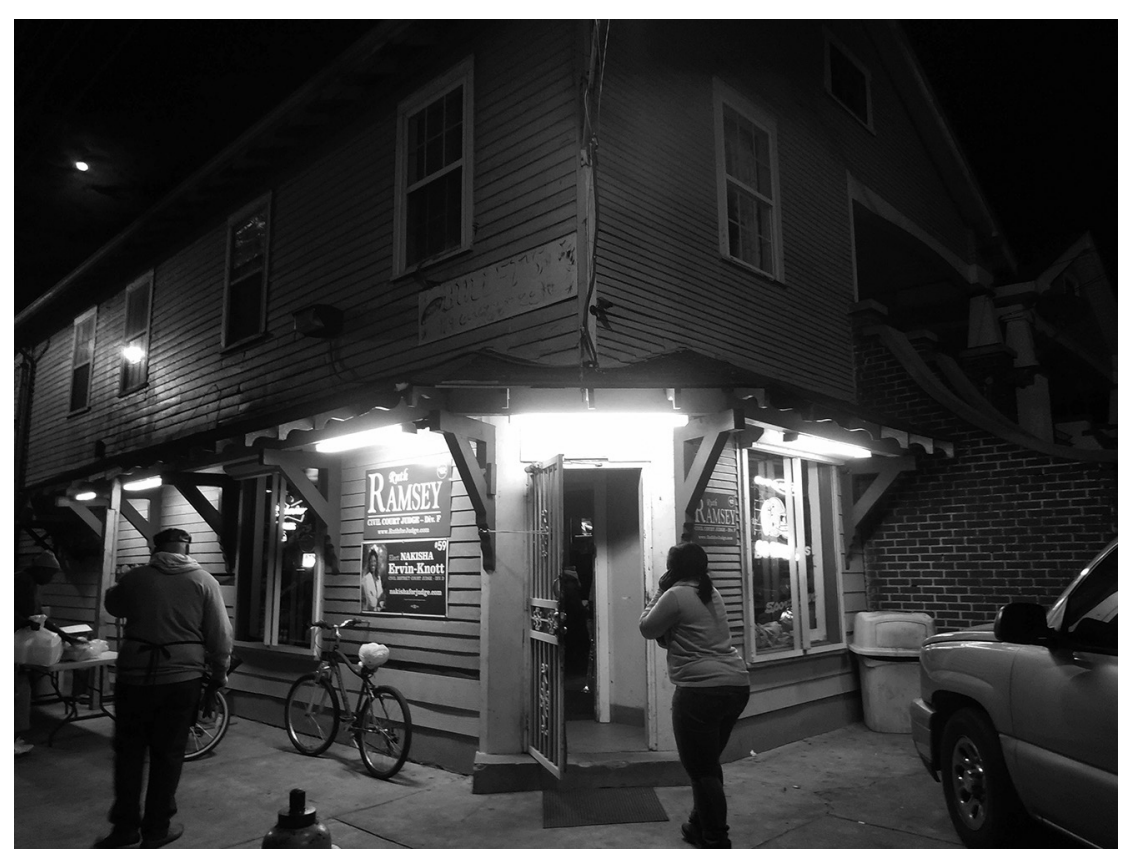

Figure 1. The exterior of Bullet's Sports Bar, January 9, 2015. (All photographs by the author.)

exclamatory remark about how much I'm looking forward to their set. I walk through the doorway into the reddish hue of the bar's lights and greet the Friday night doorman, Brian Garcia, with a grasped hand and a pat on the back. I immediately think of part of historian Joan Scott's (1986) foundational definition of gender as an element of social relationships that relies on perceived differences between the sexes. Gender affects the way I interact with the Pinettes and with Brian. Normalized behavior for a straight man solicits a hug to greet women and a handshake, hand grasp, pat on the back, or any combination thereof to greet a man. Brian and I both greet each other warmly but perform our heterosexuality, ensuring that no one in the bar could confuse our affability as intimacy; a quick back pat and I'm on my way. The minutiae of these interactions are instances of elucidation that speak to more than simple habitual actions (Geertz 1973). I enact these interactions on the fly, realizing that they are both performative and normative and are instrumental to my navigation of the field.

Inside Bullet's, I walk over to the bar, where Kendra Robertson, the Friday night bartender, greets me with a smile and offers to serve me one of my two 
usual beers: "Hey, baby! What will it be today—a Bud Light or a Red Stripe?" Feeling spendthrifty, I decide on the more expensive of the two, and she hands me a bottle of Red Stripe. “Thanks so much!" I exclaim happily, handing her a tip. I start most of my Fridays this way and find the weekly routine both ritualistic and comforting. I enjoy chatting with the other regulars, and because of my working-class background, I feel far more at home here than I would at a bar where you're required to take off your hat and the bartenders call themselves "mixologists." In an interview with the Pinettes' jovial and talkative tuba player, Janine "Tuba Shorty" Waters, she described the friendly atmosphere of Bullet's as a "Seventh Ward thing": "Me and Christie are from the Seventh Ward, and we're always like, 'Well, you're not from the Seventh Ward. You wouldn't understand.' We walk up the street, and we speak to people, and we just do things different from Uptown people.... It's different" (Janine Waters, interview with the author, November 5, 2014, New Orleans, Louisiana).

Every Friday when I arrive at Bullet's I am greeted by many of the regulars, who, like me, ritually come to their favorite watering hole as a means of unwinding at the end of the workweek. The audience present on a Friday night at Bullet's constitutes a public: "a concrete audience, a crowd witnessing itself in visible space" (Warner 2002:66). The Friday night public at Bullet's is bound temporally and spatially, and my own participation is voluntary and provisional, circumscribed by my Canadian citizenship (and lack of US citizenship) and the peripatetic life that comes with being a long-term student and academic; there's no way for me to know how long I can remain a regular at the bar because my ability to stay in the country is contingent on jobs and academic programs. I'm usually only one of a handful of white people there, and I'm thirty years younger than many of the bar's black clientele. Michael Warner contends, however, that a public relies not on the categorical classification of its members, on objectively determined position in social structures, or on members' material existence. Rather, the creation of a public hinges on the activities of its members; publics, Warner argues, "resemble the model of voluntary association that is so important to civil society" (88). A public is a self-organized group that exists outside the categorization of its members or formal institutions. I am a member of the Friday night public at Bullet's simply because I take part in its discourse and not because of any facet of my identity. Over my time there I've befriended many of the regulars, who frequently tell me stories and impart life lessons. We buy each other drinks; dance and eat together; talk about football, local traditions, and political issues; and sing along with the Pinettes. Discourse at Bullet's includes not only spoken communication and acts like singing along but also bodily communication via dancing, which has often functioned for me both as a means of responding to the music and as an avenue into discussion with others. 


\section{“Casanova”}

It's a slow night at Bullet's, and the patrons have thus far remained seated. Brass bands in any setting function to move bodies, and the Pinettes, several songs into their first set, are still working to get people out of their seats. In an interview, Dee Holmes, the band's soft-spoken trombonist, stated her aim when onstage with the Pinettes: "I just want them to move their bodies. I want them to feel what I'm playing. I want them to get into the groove of what we're giving you. You know? I want them to receive us. Make me feel like I'm playing my horn for a reason" (interview with the author, April 25, 2014, New Orleans, Louisiana). Certain songs in the brass band repertoire instantly elicit a response from audiences familiar with the music, and "Casanova," a required tune for any brass band, is one of them. Veronique Dorsey, the Pinettes' laid-back and dreadlocked trumpet player, told me that if the band refused to play "Casanova" at someone's wedding, the customer would most likely demand a refund. The song is thus necessitated by market demands. Faced with an unusually unresponsive crowd, the Pinettes decide that "Casanova" should be sufficient to energize the crowd, and they're certainly not wrong. ${ }^{4}$ Upon hearing the first few notes of the tuba line, I jump to my feet (figure 2). Christie's mother and aunt, sitting at the table nearest the band, also leap from their chairs, throw their hands up in the air, and sway their hips from side to side. I take my camera out of my pocket and attempt an awkward combination of enthusiastic footwork and steady videography that could hardly be considered successful on either front. Several others get up, proving that the song-as wielded by the Pinettes-is unrelenting in its quest to put people in motion. The song was originally a $1987 \mathrm{R} \& \mathrm{~B}$ hit by the pop group LeVert, with lyrics that imply that the protagonist is not a womanizer:

I ain't much on Casanova.

Me and Romeo ain't never been friends.

Can't you see how much I really love you?

I want to sing it to you time and time again.

Oh, Casanova ...

In LeVert's version, substantial 1980s accoutrements-staccato synth hits and a warbley synth bass that seems perfectly tailored for a tuba translation-follow this stanza. In an intergenerational, conversational book by Gerald Levert (leader of LeVert) and his father, Eddie Levert Sr. (leader of the O'Jays), the senior Levert argues that "young black men have to get past this macho sex thing they have. They walk around acting like all women are bitches and they gotta be the pimp. They've got to get past looking at women as sex objects" (Levert, Levert, and LeFlore 1997:93). Gerald Levert ostensibly took a page out of his father's book for "Casanova," which makes the rewrite of the lyrics by the Rebirth Brass Band all the more shocking. When Rebirth revised the song to fit the brass band 


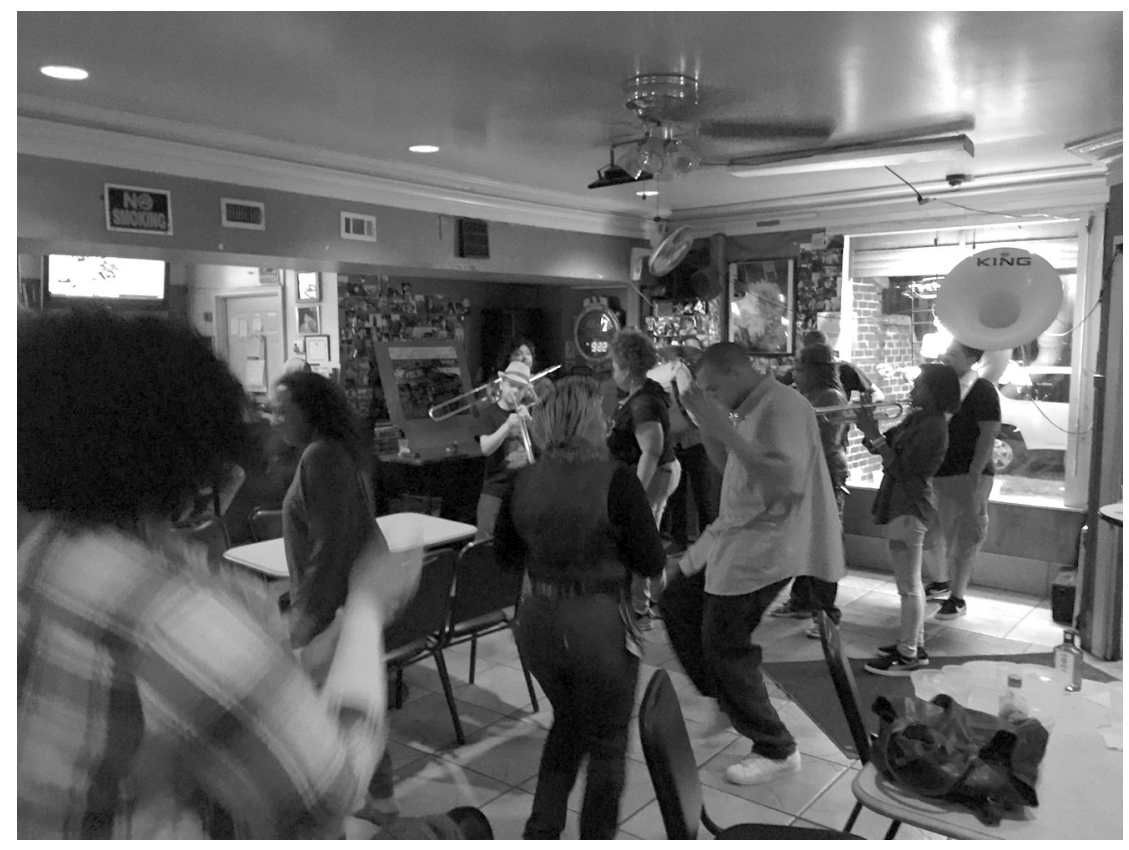

Figure 2. Patrons take to the dance floor as a boy in a fedora sits in on trombone, November 27, 2015.

tradition on their 2001 album, Hot Venom, they took substantial liberties with the lyrics so that the song holds a much different meaning:

I ain't much on Casanova.

Me and Romeo ain't never been friends.

Can't you see how much I want to fuck you?

Come and sing it to you time and time again.

Oh, bitch bend over...

(Take 'em off, take your motherfuckin' drawers off.)

This song and others like it circulate through the homosocial brass band community. While systems of class, race, sexuality, and gender all intersect in music, "Casanova" really brings gender and power under the analytical microscope in its blatant objectification of women. A central feature in Rebirth's adaptation of "Casanova," objectification serves to set binary systems of oppression in motion (Collins 2000:70-71). In the retuned lyrics of "Casanova," women are sexually objectified as the Other and viewed as objects to be manipulated and controlled. As feminist scholar Catharine MacKinnon so bluntly put it, "Man fucks woman; subject verb object" (1989:124). 
The Pinettes, however, have a different approach to the song. Leaning into the microphone, Veronique begins singing the words to "Casanova." The lyrics the Pinettes tend to sing are different from the ones sung by Rebirth. Rather than singing "bitch bend over," Veronique replaces the phrase with the original lyric, "Oh, Casanova," and instead of "Can't you see how much I want to fuck you?" she reverts the lyrics to their original "Can't you see how much I really love you?" She retains Rebirth's instructions to the subject of the song to take his or her clothes off, although she delivers the line without expletives, making it easier to use across different audiences.

\section{I ain't much on Casanova.}

Me and Romeo ain't never been friends.

Can't you see how much I really love you?

Let me sing it to you time and time again.

Oh, Casanova ...

(Take 'em off, take all your clothes off.)

In singing "Take all your clothes off” and various other sexual/textual interpolations, the Pinettes change the gendered meaning of Rebirth's addition to the lyrics. Referencing trombonist Nicole Elwood's insistence on this inclusion, Veronique told me with a chuckle, "But she's talking about a man, not what Rebirth was saying!" (Veronique Dorsey, interview with the author, September 17, 2014, New Orleans, Louisiana). ${ }^{5}$

The Pinettes challenge controlling images of blackness that differ greatly from those of their male colleagues. Specifically, the Pinettes push against racist constructions of female sexuality rooted in the history of slavery. Collins carefully outlined the controlling images of black womanhood that work to dictate the behavior and identities of black women. These images include the tragic mulatta, the comic mammy, the welfare mother, and the hypersexualized jezebel (Collins 2000). These stereotypes "do not reflect black women's lived experiences; instead, they limit African American women to prescribed roles that serve the interests of others" (Harris-Perry 2011:96). The stereotype of the jezebel promotes an image of black women as insatiable, lustful, lascivious, and seductive. In the nineteenth century, these tropes served to harmonize the discordant commodification of black female bodies with the modesty upheld by Victorian ideals (55). Those inside and outside the brass band community promulgate this stereotype of the jezebel, albeit in a style more suited to the discourse of the twenty-first century. Rebirth's use of the term "bitch" exemplifies this discourse. The controlling image of the "sexualized bitch" as disseminated by the Rebirth recording is the modern-day equivalent of the jezebel image, but repackaged and sold to a twenty-first-century audience (Collins 2004).

While one could take the stance that the use of "take your clothes off" in the Pinettes' version of "Casanova" simply adheres to the controlling image of 
the jezebel or the sexualized bitch, I think this reading would ignore the history the Pinettes engage with. In the Jim Crow South in particular, black women responded to assaults on black sexuality by shielding it from public scrutiny. This "super morality" became the way black women dealt with the hypersexualized image forced upon them (Higginbotham 1992). Historian Darlene Clark Hine argues that "in the face of the pervasive stereotypes and negative estimations of the sexuality of black women, it was imperative that they collectively create alternative self-images and shield from scrutiny these private, empowering definitions of self" (1995:383). This creation of a deceptive exterior image has led to what Hine calls a "culture of dissemblance" in which black women shielded their inner lives from oppression under the guise of openness (380).

Music as a social expression of interiority can act as a release valve for cultural dissemblance. Louise Meintjes notes that "when other aspects of social life are severely repressed, expressive culture becomes a strategic persuasive tool for all factions and a means to open up new spaces for the disempowered" (2003:11). As I've already noted, classic blueswomen of the 1920s and 1930s and the songs they performed have been studied at length as sites of black feminist knowledge. In these songs, women were free to assert themselves publicly as sexual beings (Carby 1986; Davis 1999). ${ }^{6}$ Hip-hop also provides an arena where black women lift the mask of dissemblance (Harris-Perry 2011). Drawing from hip-hop and other contemporary cultural forms, the Pinettes clearly exercise their ability to move away from prescribed images in popular romantic ballads where the female authorial voice's expression of desire is circumscribed by bourgeois ideals of female virginity and passivity (here I'm using the excellent wording of Gayle Wald [2003]). Instead of simply replacing the Rebirth lyrics with LeVert's original lyrics, the Pinettes maintain a claim to sexuality with the insistence that the listener remove his or her garments. Other textual interpolations also surface. For instance, saxophonist Natasha Harris, making reference to a song called "HBNS" by Rebirth, often shouts, "We want hot, butt-naked sex!" during the song. As Gerald Levert declared of his musical intentions, "For us it's always been about creating music that's telling the truth about what men and women want. Sometimes women want it just as bad as men!" (Levert, Levert, and LeFlore 1997:126).

"For African Americans," argues Collins, "rejecting what is expected is often the first step in resistance" (2004:18). What the Pinettes do is more than just resistant-it's revolutionary. While they push back against objectification in the first part of the song by reverting to the LeVert lyrics, they also make it clear that they have no qualms about being sexual, instructing men in the audience to "take all your clothes off." In their hands, the song becomes a powerful selfdefinition that goes beyond just "rejecting what is expected" and moving toward crafting a collective image on their own terms. 


\section{"Baby"/"Valerie"}

Over the clave rhythm of the tuba and bass drum, saxophonist Natasha Harris seizes the stage with her commanding presence. She dedicates the next song, proclaiming to the audience, "Awwwwww yeah! Now we gonna do a little song made famous by Ms. Amy Winehouse, y'all. We call it 'Baby', she calls it 'Valerie.' We do this one for her. ... RIP to my girl Amy!"

Natasha emphatically intones the eulogy, raising and dropping the pitch of her voice on "A-my," while the other band members answer in unison, "RIP to my girl Amy!" (figure 3). With this shouted tribute the Pinettes launch into "Valerie" by British neo-soul singer Amy Winehouse, who before her untimely death in 2010 was widely considered a feminist figure, uncompromising in her insistence on self-definition. ${ }^{7}$ Her hit "Valerie" is among the woman-centric songs most frequently performed by the Pinettes. In fact, I don't remember the last time I was at a gig where they didn't play it. As Natasha notes, however, rather than call the song "Valerie," the Pinettes have curiously changed the title and hook (in the last line of the following stanza) to "Baby."

Since I've come on home,

Well, my body's been a mess,

And I miss your ginger hair,

And the way you like to dress,

Won't you come on over?

And stop making a fool out of me?

Why don't you come on over, baby?

When I asked Veronique about the change of the hook and title, she deferred to the band's leader, Christie, whose decision it was to make the changes. The explanation she offered at least partly concerned making the song their own, but I couldn't help but read a little deeper into what social forces might be at play.

VERONIQUE: Honestly, you might have to ask Christie, because, honestly, I'd never heard the song before until I got with the Pinettes, so I thought the name of the song was "Baby," and then I heard Amy Winehouse and I was like, "Valerie? Where did that come from?" I think also they changed it to "Baby" because they wanted to make it, like, a Pinettes song, because even though it's "Valerie," once we start playing it, it's like a total different song and a different feel. So I think that's partially the reason why, but the rest...

KYLE: Because I mean, I asked Christie one time, and the answer she gave me was super ambiguous. She said, "We didn't want anyone to have mixed emotions." And I was like, "Oh, okay. I don't really know what you're getting at here. I mean, I can kind of guess."

VERONIQUE: Yeah. And because you're singing "Valerie ..."

KYLE: And, you know, with the protagonist of the song being a woman.

VERONIQUE: Yeah, that's probably it, too. Because-even on stage sometimes-I have to remember I'm gay, but [everyone in] the band's not gay, so I have to watch 


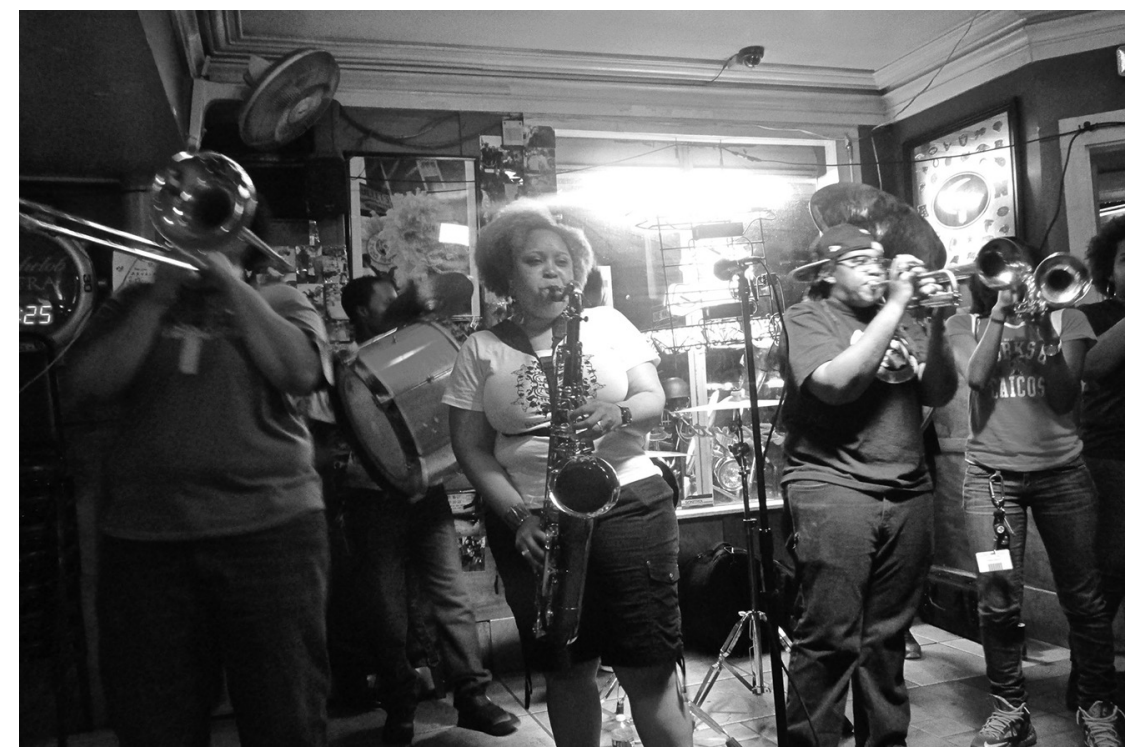

Figure 3. The Pinettes' front line. Left to right: Dee Holmes (trombone), Natasha Harris (tenor saxophone), Veronique Dorsey (trumpet), and Jazz Henry (trumpet), September 26, 2014.

my language and what I say. Yeah, even when we sing songs like "Casanova," we have to change the language because we don't want people to think we're just singing like the guys. (Veronique Dorsey, interview with the author, February 22, 2015, New Orleans, Louisiana)

By changing the name and hook of the song from "Valerie" to the genderneutral "Baby" in the last line, the Pinettes have attempted to ungender the subject of the song and remove homosexuality from the conversation. Were they to sing a song of lost love about a woman, their male colleagues might label them lesbians, and this "accusation" of lesbianism would ostensibly carry with it a dismissive quality. The Pinettes sing a gender-neutral version of the lyrics because playing male-gendered instruments, in the words of feminist jazz historian Sherrie Tucker (2000), often leads to the identification of women as "sexually suspect." Tucker makes the case that "women in all-girl bands were sexualized throughout their careers. Those who played nontraditional instruments aroused suspicions that they must be nontraditional in other ways as well" (22). While Tucker refers to the "all-girl" swing bands of the 1940s, the belief that women who play in all-female bands are lesbians persists unbridled into the present. Dee Holmes and I had a frank discussion about sexuality that 
indicated the persistence of this idea. Dee is usually quite soft-spoken, but the thought of instrument selection or her own sexuality further marginalizing the entirety of the band got her blood boiling.

DEE: Just because a couple of us are [gay], it doesn't mean that the whole band is, you know? I mean, we're just talented women. We want to be seen in the game just like you are. ${ }^{8}$ I mean-me personally-close your eyes. We're musicians, that's it. We don't need that "Oh, those girls." We don't look at it and say, "Oh, those guys." You know, we're musicians. "I like the way you guys sound tonight." You know? You don't have to do all that extra stuff.

KYLE: Do you think even if all of you were straight, there would still be that inclination to say [that you're all lesbians] ...

DEE: Of course!

KYLE: Do you have any idea where that comes from?

DEE: Girls aren't supposed to play brass instruments. I mean, that's just like marching in high school bands-St. Mary's Academy. "You go to an all-girls' school, you must be gay." They thought about us like that when we were in high school. So I don't know. I think women aren't capable in their eyes. (Dee Holmes, interview with the author, August 22, 2014, New Orleans, Louisiana)

As black lesbians, Veronique and Dee are subject to multiple intersecting systems of oppression. Dee recognized the burden that comes with being on the "deviant" or nonnormative end of racial, sexual, and gender binaries, telling me, "I don't know. I guess I'm a triple negative, huh?" (Holmes, interview, August 22, 2014). Though she told me this with a laugh, the gravity of Dee's observation should not be taken lightly. As Collins notes, "In essence, to be completely 'normal,' one must be White, masculine, and heterosexual, the core hegemonic White masculinity. ... Its antithesis, its Other, would be Black, female, and lesbian " (2004:96-97). My interactions with Veronique and Dee take place over these multiple systems of oppression. Gender, sexuality, and race shape every aspect of my research, including my entrée, the band's trust in me, my relationships with individuals in the band, and the epistemological tools available to me.

Early on in my research, when I asked Christie about changing the name and the hook of "Valerie" to "Baby," she responded opaquely, telling me, "We didn't want anyone to have mixed emotions." In doing this, she used ambiguity as a form of self-censoring protection because at the time she wasn't sure how I would respond to an outright discussion about sexuality. Her active opposition to being labeled a lesbian stems from a history of women musicians being perceived as sexually suspect and also the further oppression and marginalization that come with nonnormative sexualities. Black law scholar Harlon Dalton suspects that, at least in the African American communities, "openly gay men and lesbians evoke hostility in part because they have come to symbolize the strong female and the weak male that slavery and Jim Crow produced... Lesbians are seen

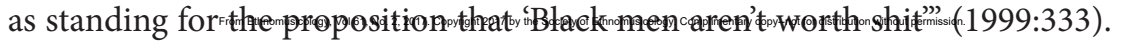


In the generally sexually repressive society of the United States, adhering to normative societal roles can act as a survival technique.

There exists an inherent self-censorship when any hierarchy invades interpersonal relationships, and Christie's use of ambiguity is one example of this. This censorship colored Christie's early relationship not only with me but also with other brass band musicians and audience members. ${ }^{9}$ This is an example of what postcolonial theorist Gayatri Chakravorty Spivak has termed "strategic essentialism," in which people temporarily put aside intragroup differences to achieve social action (1984-85:185). While the identities of members of the Pinettes are substantially variegated (encompassing, most notably, differences in sexualities and ages), they often unite in a brass band as women in a defiant act of strategic essentialism that disregards intragroup differences in favor of a united front for social change. Dee put it quite succinctly when she told me, "We promote female power." As astute businesswomen, the Pinettes very consciously leverage their collective gender identity as a means of marketing themselves and carving out a niche in the larger brass band market. Strategic essentialism, in this case, is in close conversation with what the business world would term "strategic differentiation." Racial formation theorists Michael Omi and Howard Winant argue that "social movements create collective identity by offering their adherents a different view of themselves and their world" (2015:165, emphasis mine). Despite variations in sexuality within the band, the Pinettes craft a collective identity that they leverage to offer audiences a different view of the brass band community, one in which women command brass band instruments. The example of "Baby" shows us that musical subversion is not always total but rather subject to and informed by the lived social experiences of musicians.

By deconstructing "Casanova" and "Baby," I situate the Pinettes and their music within a complex field of identity politics. Angela Davis's claim that "not all progressive art needs to be concerned with explicitly political problems" rings true, but by looking at the decisions the Pinettes make on and off the stage, we can go a step further to better understand the progressive politics that are at play and the artists' agency in these political decisions (1990:200). The Pinettes play with the lyrics of "Casanova," carefully deciding on how they will deal with the sexual objectification of women. Rather than use either of the existing versions of the song's lyrics, the Pinettes modify them to their will, expressing self-definitions that reject and respond to the sexual objectification of the brass band version. As the case of "Baby" illustrates, their subversion of oppression is not always total and becomes complicated when performing a collective identity in a band that encompasses multiple sexual identities. Self-definitions require the individuated self, but a united collective front is crucial in subverting maledominated musical genres. Taken together, these songs provide knowledge of the Pinettes' lived experience and the identity politics that are bound up with

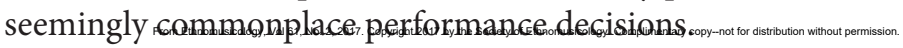




\section{Gendered Instruments}

Across cultures, musical instruments have been intimately linked to gender and sexual ideologies (Koskoff 2014). As I've already noted, women who play traditionally masculine instruments elicit audience reactions that call into question their sexual orientation. Veronique specifically singled out male brass band musicians for making the assumption that the members of the Pinettes are all lesbians, telling me, "[Brass band musicians] don't expect nonlesbian women to-or, well, straight women-to play drums or play tuba. They just expect like, 'Oh, because you are maybe more masculine because you're a lesbian then, hey, you're going to play a brass instrument or a drum.' Like, that's not the case. But that's just like a societal thing, though. People just expect that" (Dorsey interview, February 22, 2015).

When I asked Veronique how people came to ascertain the Pinettes' homosexuality through their instrument selection, she postulated, "I guess they associate drums and brass to masculinity" (Dorsey interview, February 22, 2015). People make two mental leaps when linking sexuality and instrument selection. First, there is the assumption that lesbianism is linked with masculinity. Second, there is the association of masculinity and brass band instruments. It is through these two associations that lesbianism and brass band instruments become intertwined. As Veronique notes, getting to know the Pinettes disentangles these relationships, partly because one would realize that only 20 percent of the band is homosexual, but also because to get to know someone-and to hear them-is to internally grant them their subjectivity and allow for an array of self-definitions beyond societal categorization. ${ }^{10}$

Theorizing musical instruments cross-culturally, Veronica Doubleday (2008) argues that humans construct gendered meanings through the relationship between musical instruments and the musicians who play them, and it is through enforcing these relationships that one gender can maintain exclusive control over a musical tradition. Frequently, musicians play instruments with gendered meanings that correspond to their identities: men play brass band instruments, which are also gendered male, for example. Drawing from the physical features of the trumpet and the performance gestures of its practitioners, Krin Gabbard (1992) uses psychoanalytic theory to argue that within the context of the United States, the trumpet is a phallus, and instrumentalists use it to voice phallic authority. This argument, though seemingly phallogocentric and complicated by the existence of the Pinettes, holds true for most New Orleans brass bands, just as it does in most American musical traditions. In these brass bands, the instrument and the musician establish a same-gendered relationship that in turn renders the brass band the domain of men. The relationship between malegendered instruments and the women who seek to play them is often obstructed 
by a "negative instrument-human relationship" (Doubleday 2008:5). "In terms of traditions and conventions," notes Doubleday, "it is uncommon for a woman to play an instrument that has a clearly established masculine identity" (14-15). This is because-at least within the confines of societal norms - the relationship established between a masculine instrument and a feminine performer would place the instrument in a position of greater power than the performer (14-15). Audiences and other brass band musicians reconcile this instrument-human power differential in the Pinettes using accessible stereotypes of black lesbians, who are seen as "butch bulldaggers" or as sexually voracious (Halberstam 1998). These stereotypes are convenient because they allow others-particularly males invested in hegemonic masculinity - to keep brass band instruments within a masculine domain of musicianship. These male-gendered instruments, in the hands of the Pinettes, aren't used to display "phallic authority," as Gabbard argues of the trumpet; instead, they contest the very supremacy of masculinity, unsettling the masculine and feminine associations with particular instruments. In playing these instruments and rejecting convention, the Pinettes complicate the same-gender instrument-human relationship, destabilizing the notion that there is anything natural about male exclusivity of the instruments and the genre.

The Pinettes acutely feel the tensions created by their queering of the negative instrument-human relationship and the departure from societal norms that it represents. "You know, [playing the piano is] a normal thing for a female," Janine told me, "but when you see females holding a bass drum and a tuba and a snare drum, all of that, they're like, 'Is that a girl?' You know? And they're just kind of stunned." This possible misrecognition of gender and the sense of surprise it elicits is a common reaction when audiences see women playing male-gendered instruments (Tucker 2000). Janine seemed frustrated by audience surprise, noting that it prevents people from enjoying themselves: "They're so shocked and surprised that it's all females. So by the time they get over that, we're done playing. So it's like they're standing up looking, making sure everyone on every instrument is a female, and they can't even get into the music because they're so busy paying attention to the female thing" (Waters, interview, November 5, 2014).

Janine's experience playing music in school illustrates the obstacles in playing and sticking with instruments typically played by men. She received musical schooling at both a girls' school and a coed school.

I went to St. Mary's for two years, and then I finished from John McDonogh [High School].... But my experience was awesome because I was the only girl—of coursetuba player. So I was surrounded by guys who band was their life. I wasn't supposed to go to John McDonogh, but I went to the band camp the summer before my freshman year, and I begged and begged, begged, begged, begged my mom to go, and I was like, "Please Mom, I just want to march in the band." So she let me go, 
and when I walked into band camp, I had my own horn, so they're looking at me like, "Who is this girl and where does she come from?" You know? It was only three girls in the band at the time: three trumpet players and myself. Well, four-one saxophone player. We were the minority in the band, so the guys were like, "We're going to see if they're tough enough."

But it was good. They respected me, you know? Because when I came in, I played my horn. I wasn't like, "Look, I want this spot, but I’m going to tiptoe." No, I came and I demanded respect and I got it. And so it was from the beginning, from my freshman year all the way to my senior year. I held different positions in the band, band captain and cocaptain. So, you know, once that came about, it was like, "Okay, we have to respect her. We have no other choice." It was good. My four years in high school was really good. (Waters, interview, November 5, 2014)

Janine first recalled the musicians who, like herself, strayed furthest from gender norms. The inclusion of the saxophone player as a sort of afterthought in her list of girls in the band signals the instrument's gender ambiguity. Within the United States, the saxophone has come to occupy the middle of the malefemale spectrum (Zervoudakes and Tanur 1994). Janine's experience tells us that, while the gendering of instruments often materializes in the gender disparity of school marching bands, girls do learn to play brass band instruments through formal and informal schooling. After schooling, however, the only women in New Orleans who have gone on to play in brass bands at a professional level are in the Pinettes. In Janine's case, her success at resisting the gender norms that would establish a negative instrument-human relationship with her tuba was the result of her own strong-mindedness: she demanded respect and received it. Demanding respect from her peers thus upset normative gendered behavior and destabilized the essentialist and normative notion that the tuba is a "boy's instrument."

\section{Street Queens}

The shade underneath the highway overpass in New Orleans's Tremé neighborhood provides respite from the heat of a hot late October day in New Orleans. Under the bridge between St. Philip and St. Ann Streets, the scene is set for the second Red Bull Street Kings Brass Band Blowout. ${ }^{11}$ Food trucks line the perimeter of the event, reaching from Dumaine to St. Philip Street. One block ahead (between St. Ann and Dumaine), four stages are set up, each with rigging for lighting and street art-inspired murals providing the backdrop.

Before the event begins, the four competing bands-the Pinettes, the TBC Brass Band, the New Breed Brass Band, and the New Creations Brass Bandoccupy band tents at the end of the area opposite the stages. The TBC launch into a few warm-up tunes to prime the small crowd around their tent. They segue into "You Don't Want to Go to War," a tune from the Rebirth catalog that warns 
other bands not to engage with them in musical battle. Musical shots are fired. Not willing to back down, the New Creations Brass Band retaliate with another fiercely competitive tune called "Let's Go Get 'Em." As if to call TBC's bluff, they also play “Talkin' Loud and Sayin' Nothin," originally by James Brown. In the two tents removed from the brass band battling, the Pinettes and New Breed watch on, anticipating the stiff competition. ${ }^{12}$

By the time the competition proper starts, thousands of people occupy the area under the overpass (figure 4). To begin, bands parade from one side of the demarcated area to the other, ending up on their respective stages. The first three bands parade in in the usual fashion for second lines. Few frills are added, except for large groups of fans and revelers and an especially large banner that follows the New Creations. The Pinettes, however, have a show in mind. Unlike their competitors, they start with a traditional jazz funeral dirge, "Just a Closer Walk with Thee," while pallbearers in the Pinettes' entourage carry a large polystyrene coffin with the names of each rival band painted on top. At the end of the dirge, the body is "cut loose," as per the tradition, and the lid on the coffin flies off. ${ }^{13} \mathrm{~A}$ dancer pops out of the coffin, much to the surprise of everyone crowded around.

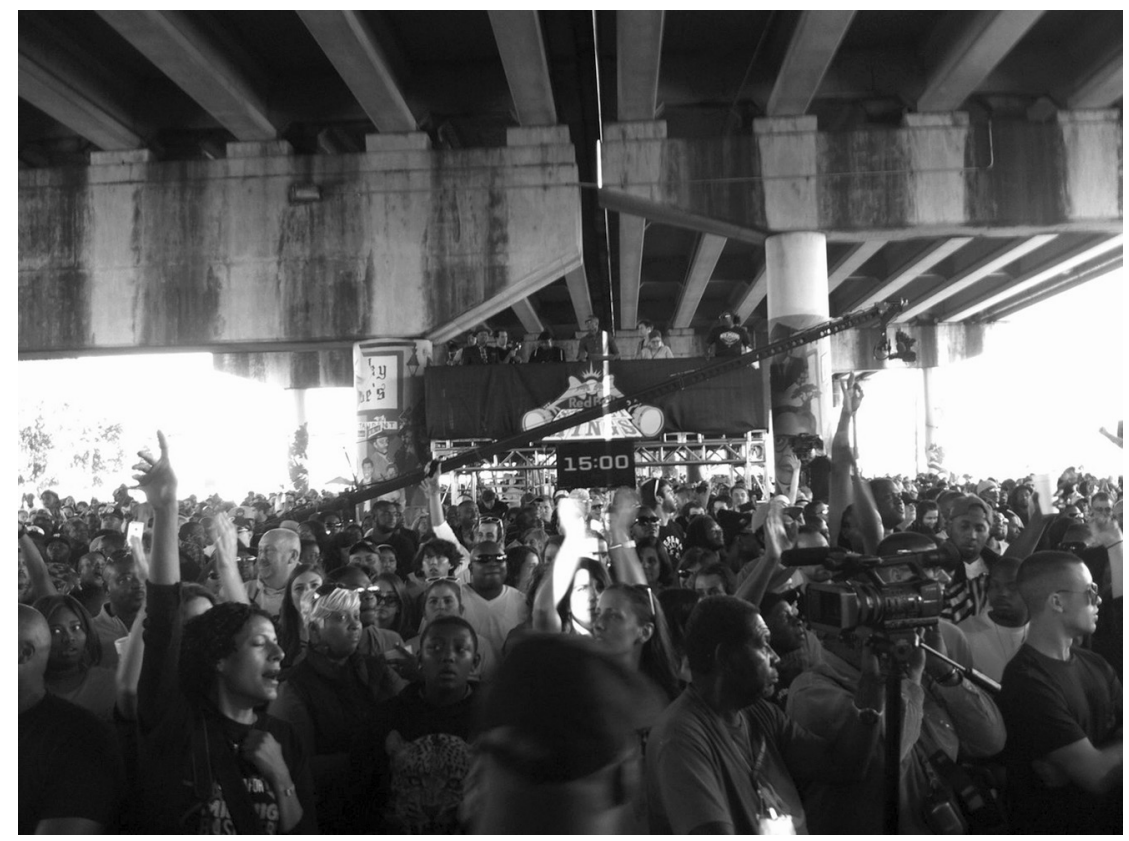

Figure 4. The judges' platform, rising over the crowd, as seen from the foot of the stage at the Red Bull Street Kings Brass Band Blowout, October 26, 2013. 
The Pinettes loudly blare "Rebirth Melody," a boastful track from Rebirth's most hip-hop-influenced album, Hot Venom. Confetti cannons spew shiny paper shrapnel into the air, and the band members take off and throw their white button-up shirts (traditional jazz funeral attire) into the tightly packed audience, revealing white and blue baseball shirts embellished with the band's logo. The Cherry Bombs, an all-female New Orleans dance troupe, bounce umbrellas with the words "Street Queens" written in red and blue sparkles. Members of the crowd throw their hands up in the air and bob to the syncopated blasts of the tuba. The elaborate choreography of the funeral sets the Pinettes apart, and by transitioning to a tune by the consummate Rebirth Brass Band, who occupy the top rung of the brass band patriarchy, the Pinettes further advance a clear message of competition to the other bands: they are a formidable musical force and should not be taken lightly.

As the bands cycle through the songs of the first round, it's clear that the Pinettes have put significant time and preparation into their stage show. To everyone's surprise, TBC, the crowd favorite (and de facto "street kings" who provide music weekly for community parades), are eliminated after the first round along with the New Creations. I can feel the anticipation mounting in the crowd as the final round of the competition is about to play out. The two bands that have made it to the final round - the Pinettes and New Breed-stand poised to play at the far right and far left stages, respectively. Fulfilling their hosting duties, trombonist Glen David Andrews and hip-hop DJ Slab 1 work the audience into a frenzy. The audience directly in front of the Pinettes' stage is mostly clad in red and blue Pinettes regalia that aligns with the colors of Red Bull's brand. Christie's mother, wearing a blue Pinettes shirt, a red ten-gallon hat, and a matching boa, cheers the band on. The audience, familiar with the Pinettes' music, loudly requests one of the band's signature originals, "Get a Life." Later, Christie reflected on the competitive spirit that took hold of them in that moment:

CHRISTIE: Glen David [Andrews] said, "We going to see who's going first. . . ." I said, "We going first!" And he was like, "Like that?" I said, "Yes." And I looked at them and said, "We going to set the bar. Now they set it high, then we got to come knock it down. So we gonna set it up as high as we want." And the audience hollering, "Get a Life!" the whole time. ... So, you know, why not? And Jenard [Andrews, of the New Breed Brass Band], the snare drummer, he even said, [in a mocking tone] "Y’all gonna play 'Get a Life'?" .. . but the people was like, "Get a Life! Get a Life!” Okay, not a problem.

KYLE: Sure. Do what the people want. I guess so!

CHRISTIE: That's it. You've got to give them what they want. (Jourdain, interview, March 17, 2014)

And the Pinettes give the audience exactly what they want. The back row launches into "Get a Life" as the front line yells the introductory refrain in 
unison: "Get a life! Get, get, get, get, get a life!" The second the booming tuba arpeggiation begins, the crowd erupts, pleased that their request is fulfilled. At the foot of the stage, one of the band's fans spins a white sign with "The Original Pinettes" emblazoned on one side and "Street Queens" on the other.

The lyrics to "Get a Life" were penned by Christie as a means of venting frustrations with former band members. After Hurricane Katrina in 2005, some of the older band members left the group. Christie, Janine, and Casandra wanted to keep playing, but a dispute over the band's name began. By adding "Original" to the beginning of the band's name, Christie's faction claimed ownership of the name and avoided a legal challenge. The lyrics, which dealt with the feud, were direct and left no room for misinterpretation.

Won't you get a life,

'Cause you're some miserable bitches, miserable bitches!

Fuck you. Don't be mad.

'Cause we're Original Pinettes, the Original Pinettes!

Get a life! Do you and I'm 'a do me.

Get a life! Do you and I'm 'a do me.

Get a life! Do you and I'm 'a do me.

Biiiiiitch!

The meaning of the text is quite clear when you know the context of its writing. Contextualized in the larger brass band community, however, the song takes on new meaning. In the fiercely competitive realm of brass band music, playing a song like "Let's Go Get 'Em" or "You Don't Want to Go to War" is a means of intimidating and engaging in competition with other bands. When recontextualized, "Get a Life" takes on this same competitive quality.

Furthermore, the word "bitch" carries double meaning. In reference to women, the term denotes a woman with an attitude that either is "undesirable" or doesn't conform to one's normative concepts of how a woman should act. While the Pinettes remove "bitch" from the sexually objectifying lyrics of "Casanova," they make it a prominent feature in "Get a Life," in which they draw it out to near-comedic proportions. Collins notes that the term, in its most common use, "is designed to put women in their place" (2004:123). It is a term that people use to subordinate others. As a verb, it denotes trivial and negative speech, but as a noun, it presents others as servile. I suspect the term's use in "Get a Life" carries with it a sense of betrayal, as the band's former members attempted to erode the communal ties that are crucial to subversion of the brass band patriarchy. When directed at a male band, however, the term "bitch" denotes a man who holds less power than a woman or a man who is objectified as a woman. It signifies an inversion of the gender system and subverts the brass band patriarchy. Directing this term at male brass bands elevates the Pinettes to a relative position of power in the male-dominated brass band tradition. If the 
conventional relationship between female musicians and male-gendered brass band instruments places women in subordinate positions, their insistence on flipping normative power structures helps to queer this relationship. Not only do they unsettle the nonnormative human-instrument relationship between the Pinettes and their instruments, but in redirecting the term "bitch" - the same term levied at women in "Casanova" - they also disrupt the same-gender relationship between male musicians and their instruments.

The Pinettes' performance at the Red Bull Street Kings Competition was one performance where they directed "Get a Life" at a male band. In the final round of the competition, with a huge audience of cheering fans at the foot of the stage, the Pinettes launched into the tune with considerable vigor. Recounting that moment, Christie playfully attempted to remove the band's agency in the decision to play "Get a Life," telling me with a sly grin, "It was like, 'We're going to play it.' Nothing personal to New Breed. That's what they want. That's what the people want" (Jourdain, interview, March 17, 2014). By indirectly calling other brass band musicians bitches, the Pinettes dethrone the very idea of "street kings," reclaiming the term "bitch" to contest male domination of brass bands. "Get a Life" illustrates the situatedness of music's meaning. In one context, a song

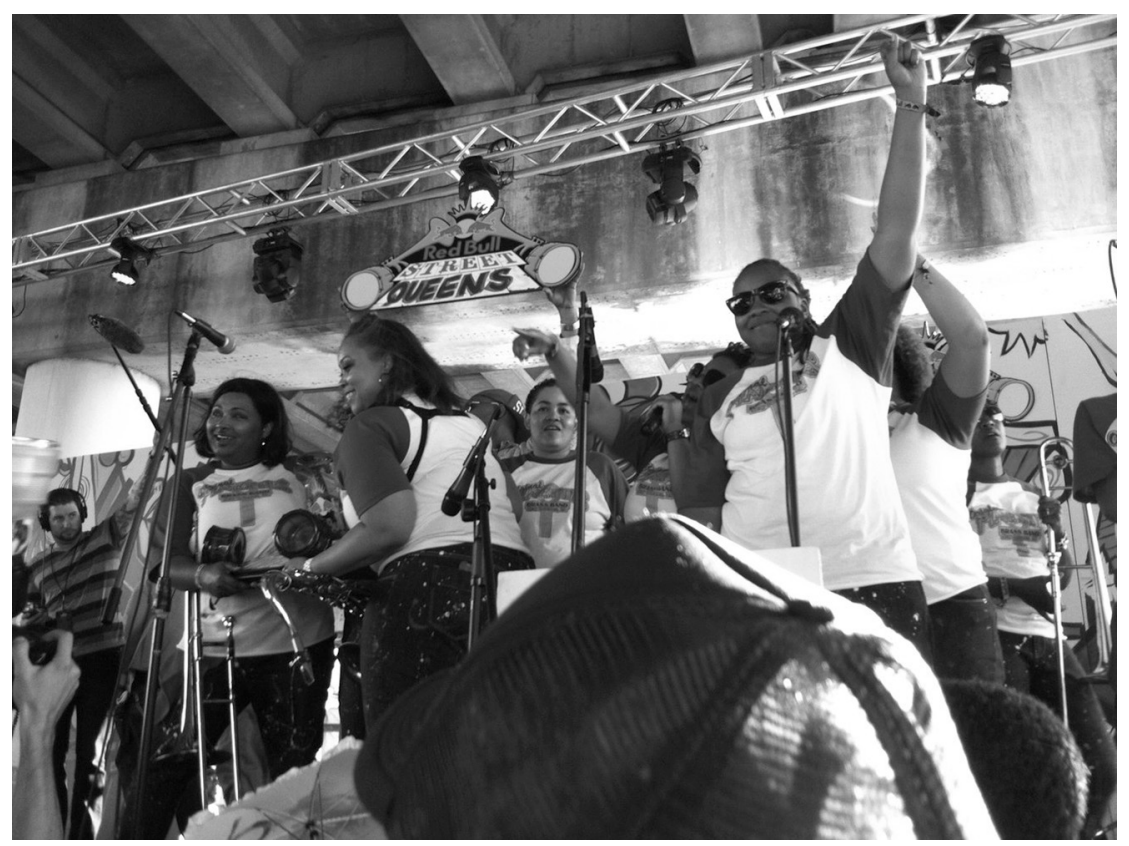

Figure 5. Veronique Dorsey triumphantly raises her trumpet in the air as Dionne Harrison (left) and Natasha Harris (right) pose with their trophy, October 26, 2013. 
can be an expression of discontent. In another, it becomes a means of unsettling conventional power structures. This use of the song suggests that the Pinettes, empowered by their music, rule the brass band scene. The song, brandished in this manner, becomes a feminist contestation of patriarchal rule in the brass band community. Using this song, they imagine themselves as all-powerful subjects or "Street Queens."

The sun begins to dip below the overpass as the two remaining bands wait in anticipation for the final verdict. Walter Ramsey, one of the judges and an accomplished brass band musician in his own right, takes hold of the microphone and, from the judges' platform in the center of the crowd, breaks the tension. "The votes are in! The Pinettes win!" Fists raised in the air, the Pinettes and their audience at the foot of the stage jump up and down with elation, much to the chagrin of New Breed and their audience (figure 5).

In a radical upending of the brass band patriarchy, the Pinettes loudly disrupt social norms with the blasts of brass and percussion instruments. Working their way inward from the margins of the brass band community, they have contested normative instrument-human relationships and used their songs and performance decisions to subvert the brass band canon and the patriarchal musical tradition it upholds.

\section{Acknowledgments}

I would like to thank Matt Sakakeeny, Dan Sharp, Karissa Haugeberg, Sue Mobley, Chris Willoughby, Sherrie Tucker, and Maddie Schwartz for providing brilliant feedback on drafts of this article, and countless friends and colleagues whose comments during Q\&A periods and over drinks have been tremendously helpful. Of course, many thanks are also due to Kendra Robertson, everyone at Bullet's, and the Pinettes past and present (especially Veronique Dorsey, Christie Jourdain, Dee Holmes, Janine Waters, and Tylita Curtain, who sat for interviews) for teaching me so much and making Friday a highlight of my week. This research was made possible by the support of the Tulane University School of Liberal Arts. I happily welcome feedback and can be contacted at kyle.a.decoste@gmail.com.

\section{Notes}

1. Though contractions are not used much in formal academic writing, I use them quite liberally. When I quote people I have interviewed, I see my use of contractions as a means of leveling the playing field of authority and keeping things conversational between the people in this essay and me. Contractions also challenge the idea of me being the singular "voice of authority."

2. This is not to say that black feminism is a free-for-all, unbounded discipline lacking an intellectual history (see DuCille 1994; Bay et al. 2015).

3. Ellen Koskoff takes note of polyvocal ethnography and the possibility that acknowledging power differentials between voices might highlight inequality (2014:101).

4. When Bullet's is only filled with diehard bargoers, barroom songs tend to do the trick. Among these barroom songs are Teddy Pendergrass's "When Somebody Loves You Back," Lebrado's "I'm Missin' You," and Mel Waiters's "Got My Whiskey." 
5. This is not to say that all band members address the lyrics to men but rather that the song is received by most audiences that way, and it's understood as a collective standpoint.

6. This has been explored to such an extent that the subtitle of Eileen Hayes and Linda Williams's edited volume Black Women and Music is More than the Blues.

7. "Valerie" originated with the Zutons (2006) before being covered by Mark Ronson (2007), who recruited Winehouse to sing it. In North America, at least, the song is very strongly associated with Winehouse, and the Pinettes themselves consider it an Amy Winehouse tune, often singing in the intro the refrain "RIP to my girl Amy!" (itself an adaptation of "RIP to my girl Shorty" in New Orleans bounce artist Keedy Black's "Hammer").

8. Though it's not clearly communicated in text without Dee's intonation, it was clear in person that the "you" in this sentence referred to male brass band musicians rather than me.

9. These hierarchies are not static but rather shift over time and in different settings.

10. For a more sonic treatment of this, see Novak and Sakakeeny (2015).

11. The first event was held in 2010 and was won by the Stooges Brass Band. The bridge under which the event takes place is the same one from Sakakeeny (2010).

12. It's interesting to note that all of these competition-driven songs are Rebirth arrangements, showing just how much the band has contributed to the brass band game and how the tunes flow from the band arguably at the top of the brass band patriarchy.

13. For an overview (and analysis) of New Orleans funeral traditions, see Regis (2001).

\section{References}

Bay, Mia, Farah J. Griffin, Martha S. Jones, and Barbara D. Savage, eds. 2015. Toward an Intellectual History of Black Women. Chapel Hill: University of North Carolina Press.

Burns, Mick. 2006. Keeping the Beat on the Street: The New Orleans Brass Band Renaissance. Baton Rouge: Louisiana State University Press.

Carby, Hazel V. 1986. “It Jus Be’s Dat Way Sometime: The Sexual Politics of Women's Blues.” Radical America 20 (4): 9-24.

Collins, Patricia Hill. 1998. Fighting Words: Black Women and the Search for Justice. Minneapolis: University of Minnesota Press.

.2000. Black Feminist Thought: Knowledge, Consciousness, and the Politics of Empowerment. 2nd ed. New York: Routledge.

- 2004. Black Sexual Politics: African Americans, Gender, and the New Racism. New York: Routledge.

- 2017. "Defining Black Feminist Thought." In Feminist Theory Reader: Local and Global Perspectives, 4th ed., edited by Carole R. McCann and Seung-Kyung Kim, 384-400. New York: Routledge.

Connell, R. W. 2005. Masculinities. 2nd ed. Berkeley: University of California Press.

Dalton, Harlon L. 1999. "AIDS in Blackface." In Black Men on Race, Gender, and Sexuality, edited by Devon W. Carbado, 324-37. New York: Pantheon.

Davis, Angela Y. 1990. Women, Culture, and Politics. New York: Vintage. 1999. Blues Legacies and Black Feminism: Gertrude "Ma" Rainey, Bessie Smith, and Billie Holiday. New York: Vintage.

Doubleday, Veronica. 2008. "Sounds of Power: An Overview of Musical Instruments and Gender." Ethnomusicology Forum 17 (1): 3-39.

DuCille, Ann. 1994. "The Occult of True Black Womanhood: Critical Demeanor and Black Feminist Studies." Signs 19 (3): 591-629.

Gabbard, Krin. 1992. 'Signifyin(g) the Phallus: 'Mo' Better Blues' and the Representations of the Jazz Trumpet." Cinema Journal 32 (1): 43-62.

Geertz, Clifford. 1973. The Interpretation of Cultures: Selected Essays. New York: Basic Book. Halberstam, Judith. 1998. Female Masculinity. Durham, NC: Duke University Press. 
Harrison, Daphne Duval. 1990. Black Pearls: Blues Queens of the 1920s. New Brunswick, NJ: Rutgers University Press.

Harris-Perry, Melissa. 2011. Sister Citizen: Shame, Stereotypes, and Black Women in America. New Haven, CT: Yale University Press.

Hayes, Eileen M., and Linda F. Williams, eds. 2007. Black Women and Music: More than the Blues. Urbana: University of Illinois Press.

Higginbotham, Evelyn Brooks. 1992. "African-American Women's History and the Metalanguage of Race.” Signs 17 (2): 251-74.

Hine, Darlene Clark. 1995. "Rape and the Inner Lives of Black Women in the Middle West: Preliminary Thoughts on the Culture of Dissemblance." In Words of Fire: An Anthology of AfricanAmerican Feminist Thought, edited by Beverly Guy-Sheftall, 380-87. New York: New Press.

hooks, bell. 1984. Feminist Theory: From Margin to Center. Boston: South End Press.

Kelley, Robin D. G. 2002. Freedom Dreams: The Black Radical Imagination. Boston: Beacon Press. Knowles, Richard H. 1996. Fallen Heroes: A History of New Orleans Brass Bands. New Orleans: Jazzology Press.

Koskoff, Ellen. 2014. Feminist Ethnomusicology: Writings on Music and Gender. Urbana: University of Illinois Press.

Levert, Eddie, Sr., and Gerald Levert, with Lyah Beth LeFlore. 2007. I Got Your Back: A Father and Son Keep It Real about Love, Fatherhood, Family, and Friendship. New York: Harlem Moon.

Lordi, Emily J. 2013. Black Resonance: Iconic Women Singers and African American Literature. New Brunswick, NJ: Rutgers University Press.

MacKinnon, Catharine. 1989. Toward a Feminist Theory of the State. Cambridge, MA: Harvard University Press.

McClaurin, Irma, ed. 2001. Black Feminist Anthropology: Theory, Politics, Praxis, and Poetics. New Brunswick, NJ: Rutgers University Press.

Meintjes, Louise. 2003. Sound of Africa! Making Music Zulu in a South African Studio. Durham, NC: Duke University Press.

Murray, Pauli. 1970. "The Liberation of Black Women." In Voices of the New Feminism, edited by Mary Lou Thompson, 87-102. Boston: Beacon Press.

Newton, Esther. 1996. "My Best Informant's Dress: The Erotic Equation in Fieldwork." In Out in the Field: Reflections of Gay and Lesbian Anthropologists, edited by Ellen Lewin and William L. Leap, 212-235. Chicago: University of Illinois Press.

Novak, David, and Matt Sakakeeny, eds. 2015. Keywords in Sound. Durham, NC: Duke University Press.

Omi, Michael, and Howard Winant. 2015. Racial Formation in the United States. 3rd ed. New York: Routledge.

Regis, Helen. 2001. "Blackness and the Politics of Memory in the New Orleans Second Line." American Ethnologist 28 (4): 752-77.

Sakakeeny, Matt. 2010. "Under the Bridge: An Orientation to Soundscapes in New Orleans." Ethnomusicology 54 (1): 1-27.

- 2013. Roll with It: Brass Bands in the Streets of New Orleans. Durham, NC: Duke University Press.

Schafer, William J. 1977. Brass Bands and New Orleans Jazz. Baton Rouge: Louisiana State University Press.

Scott, Joan W. 1986. "Gender: A Useful Category of Historical Analysis." American Historical Review 91 (5): 1053-75.

Smith, Barbara. 1982. "Toward a Black Feminist Criticism." In All the Women Are White, All the Blacks Are Men, but Some of Us Are Brave: Black Women's Studies, edited by Gloria Hull, Patricia Bell Scott, and Barbara Smith, 157-77. New York: Feminist Press.

Spivak, Gayatri Chakravorty. 1985. "Criticism, Feminism and the Institution." Interview with Elizabeth Gross. Thesis Eleven 10/11 (1): 175-87. 
Tucker, Sherrie. 2000. Swing Shift: "All-Girl” Bands of the 1940s. Durham, NC: Duke University Press. Wald, Gayle. 2003. "From Spirituals to Swing: Sister Rosetta Tharpe and Gospel Crossover." American Quarterly 55 (3): 387-416.

Walker, Alice. 1983. In Search of Our Mother's Gardens: Womanist Prose. New York: Harcourt Brace Jovanovich.

Warner, Michael. 2002. Publics and Counterpublics. New York: Zone Books.

White, Michael. 2001. "The New Orleans Brass Band: A Cultural Tradition." In The Triumph of the Soul: Cultural and Psychological Aspects of African American Music, edited by Ferdinand Jones and Arthur C. Jones, 69-96. Westport, CT: Praeger.

Zervoudakes, Jason, and Judith M. Tanur. 1994. "Gender and Musical Instruments: Winds of Change?" Journal of Research in Music Education 42 (1): 58-67. 